\title{
Christelle Jullien. « La révolte des Chrétiens au Hūzestan (551) : modèles narratifs d'une historiographie »
}

\section{Rika Gyselen}

\section{(2) OpenEdition}

1 Journals

\section{Édition électronique}

URL : http://journals.openedition.org/abstractairanica/42572

DOI : 10.4000/abstractairanica.42572

ISBN : 1961-960X

ISSN : 1961-960X

Éditeur :

CNRS (UMR 7528 Mondes iraniens et indiens), Éditions de l'IFRI

\section{Référence électronique}

Rika Gyselen, « Christelle Jullien. « La révolte des Chrétiens au Hūzestan (551) : modèles narratifs d'une historiographie » », Abstracta Iranica [En ligne], Volume 37-38-39 | 2018, document 2, mis en ligne le 10 mars 2018, consulté le 27 septembre 2020. URL : http://journals.openedition.org/ abstractairanica/42572 ; DOI : https://doi.org/10.4000/abstractairanica.42572

Ce document a été généré automatiquement le 27 septembre 2020.

Tous droits réservés 


\title{
Christelle Jullien. « La révolte des Chrétiens au Hūzestan (551) : modèles narratifs d'une historiographie »
}

\author{
Rika Gyselen
}

\section{RÉFÉRENCE}

Christelle Jullien. « La révolte des Chrétiens au Hūzestan (551) : modèles narratifs d'une historiographie », BAI, 25, 2011 [2015], p. 107-120.

1 D'un point de vue éditorial, on peut déplorer un problème d'appel de notes : note 1 ne figure pas dans le texte, et les appels de note 14-17 réfèrent aux notes 15-18.

2 Après avoir passé en revue les sources textuelles, déjà connues et utilisées par les historiens, l'auteur se tourne vers deux sources syro-orientales (la chronique dite de Seert et la Vie de Mār Abba) qui n'ont pas été exploitées pour relater cet événement. Ces textes appuient l'hypothèse qu'il ne s'agirait pas d'une révolte des seuls chrétiens puisqu'aussi bien des mazdéens que des juifs y participent. Une grande place est laissée à l'examen de l'historiographie qui relate le rôle des chrétiens dans cette révolte ( $\mathrm{p}$. 109-114). Sont entre autres examinés : le schéma narratif dans lequel est raconté cette révolte, la supposée intervention du catholicos Mār Abba ou le fait que Anōšagzād qui mène cette révolte contre son père Husraw Ier était chrétien. C.J. aborde ensuite les textes qui semblent suggérer que la cause du soulèvement aurait été une taxation excessive des chrétiens.

Contribution originale, bien documentée et riche d'informations. 


\section{AUTEURS}

\section{RIKA GYSELEN}

CNRS, Mondes iranien et indien 